\section{Dr. Stanley Smith}

Dr. Stantey SMrth was born at Middlesbrough on March 7, 1883, and educated at Darlington Grammar School. On leaving school he worked in the chemical laboratory of the Darlington Forge Co., but in 1904 he entered Armstrong (now King's) College, Newcastle on Tyne, where he graduated in 1907, and took his M.Sc. and D.Sc. degrees in 1909 and 1915 , respectively.

Inspired by Prof. G. A. Lebour, Stanley Smith carried out investigations on the coalfields of Northumberland and the Carboniferous Limestone of the fells, his resulting paper (1911) on "The Faunal Succession of the Upper Bernician" being still a standard work. But, of greater importance, this research led him to take up the study of the Palæozoic corals, in which he thereafter specialized. Election to a fellowship at Armstrong College in 1910 took him to Clare College, Cambridge, where he graduated in 1912. His first paper on corals (1913), on ontogenesis and local variations in Aulophyllum, set the pattern for all his future work, for he insisted, as always, on the need for basing the revision of genera and species on the re-examination of the type specimens or, if they were unavailable, of topotypes. In his masterly paper on Lonsdaleia (1916), Stanley Smith write, "Inconstancy of detail, but conservation of the general plan, is the most characteristic feature of the skeletal morphology of Rugose genera", a statement repeatedly validated by later work. A stream of papers followed, either by him alone or in collaboration; these quickly established his worldwide reputation as the leading authority on Palæozoic corals. Of peculiar interest was his description (1930) of Valentian corals from Shropshire and Montgomeryshire, for, apart from H. A. Nicholson and R. Etheridge's classic monograph of the Silurian fossils of the Girvan area, no extensive coral fauna of similar age had been previously described. All his papers were marked by careful observation, honest interpretation, and polished presentation. They have acted as models for almost all Palæozoic coral research since, and, to quote a correspondent, "have really placed. Palæozoic coral work on its feet".

From 1913 Stanley Smith spent much time during vacations at the British Museum (Natural History), from which sprang his long association with Dr. W. D. Lang. Their collaboration resulted not only in several important works revising an extensive range of coral genera, but also in their enunciation (1930) of the concept of genomorphs, which has since been applied to other groups of fossils. The Museum published in 1940 the "Index of Palæozoic Coral Genera", of which Stanley Smith was a part-author.

His investigations into the geology of the Bristol area led to two major stratigraphical contributions, namely, his recognition of Tremadocian Shales in the Tortworth inlier of Gloucestershire (1933), and his correlation of the high Viséan fauna of the Tanhouse Beds of Yate with the upper part of the $P_{2}$ zone (1941). With G. A. Kellaway he also described the only British Jurassic stromatoporoids known (1938), while earlier (1923) the Geological Survey had published his important report on the lead and zine ores of Northumberland and Alston Moor. The award to him by the Geological Society of London of the Lyell Medal in 1947 for his palæontological and stratigraphical researches was richly deserved.

Stanley Smith was also knowledgeable in Greek and Roman antiquities. For some years he had been engaged with Mr. D. E. Eichholz, of the University of Bristol, on a new translation of Theophrastus's well-known treatise. His part was to interpret afresh Theophrastus's geological references and records, and to this he brought the same care and enthusiasm that characterized everything he undertook.

Stanley Smith spent his life in the university world. After appointments at Aberystwyth (1913-20), Bedford College for Women (1920-21), and Toronto (1921-22), he became assistant lecturer in geology in the University of Bristol (1922) and retired as reader in palæontology in 1948. He played a full part in local scientific societies, and had been president of the South-Western Naturalists' Union, of which he was honorary secretary for many years.

To work closely with Stanley Smith was to discover a gentle, generous nature, and a lively sense of humour which was always kindly. $\mathrm{He}$ was an indefatigable worker, to whom the problem of the moment was all-absorbing. He freely gave of his knowledge, though always in the humble spirit which was one of his great traits. He never lost his innate modesty nor his charming, old-world courtesy, and he would exercise the greatest patience in trying to understand another's point of view. Above all, he was a very loyal colleague and friend.

During the last few years of his life, Stanley Smith suffered from a painful affliction of his back; but despite this he kept at his research work to the end. $\mathrm{He}$ died peacefully on July 1, 1955, after a heart attack. His wife, whom he married in 1924, survives him.

H. Dighton Thomas

\section{Dr. J. B. Christopherson, C.B.E.}

John Brian Christopherson, familiarly known as 'Christo' to his friends, who died on July 21 at the age of eighty-seven, will be remembered for the varied and exciting career which he led as well as for the scientific work that he achieved. He will go down in medical history as the man who introduced the cure of bilharziasis (schistosomiasis) by intravenous injections of tartar emetic.

He had a good family and scientific background, being educated at Clifton College, Caius College, Cambridge, and St. Bartholomew's Hospital, London. He qualified in 1893 and soon afterwards was elected assistant surgeon to the Albert Dock Hospital under Mr. (afterwards Sir) James Cantlie, and he remained in London until 1901. Christopherson was therefore associated with the beginnings of the London School of Tropical Medicine and came under the influence of Sir Patrick Manson. In 1897 he took his final F.R.C.S. and eventually was elected F.R.C.P. in 1913. He was therefore doubly highly qualified. In 1901 he was swept into uniform and went to the South African War, becoming surgeon to the Imperial Yeomanry base hospital. After this experience, he joined in June 1902 the newly created Sudan Medical Service, first as the private doctor to the Sirdar, afterwards becoming director of medical services of the Sudan Government. Five years later he resigned this appointment and became director of the civil hospitals in Khartoum and Omdurman. He had now direct charge of clinical cases and made the most of the rich material under his care.

His career was once more broken by war, when he accompanied Sir James and Lady Berry's Red Cross Unit to Serbia as a surgeon. There he witnessed the break-up of Serbia and was taken prisoner by the 